\title{
USE OF LINEAR ALKYLBENZENE SULFONATE (LAS) AND POLYCARBOXYLATE-ETHER (PCE) AS REAGENTS IN IRON ORE FLOTATION
}

\author{
J. M. F. CARVALHO ${ }^{1, *}$, M. B. OLIVEIRA ${ }^{2}$, L. P. S. H. MOREIRA ${ }^{2}$, J. C. MENDES ${ }^{2}$, C. A. PEREIRA ${ }^{2}$ \\ Centro de Ciências Exatas e Tecnológicas, Universidade Federal de Viçosa \\ ${ }^{2}$ Escola de Minas, Universidade Federal de Ouro Preto \\ josemaria.carvalho@ufv.br*
}

Received 07/10/2017 - Accepted 08/11/2017

DOI: $10.15628 /$ holos.2017.6374

\section{ABSTRACT}

Flotation is one of the separation techniques that has been used by the mineral industry and its importance has increased due to its better performance in the concentration of low grade ores. Specific chemical reagents are used in flotation in order to promote the hydrophobicity control of minerals dispersed in a pulp, among them, surfactants have been studied with good results. In this study, a substance based on Linear Alkylbenzene Solfonate (LAS), and a concrete admixture based on Policarboxilate-ether (PCE) were tested as
\end{abstract}

reagents in iron ore flotation. The tests were performed in a friable hematite sample, using the microflotation technique. The Yates complete replicated factorial method for three variables and two levels was used in experimental planning. The variables evaluated was $\mathrm{pH}$ (9-11); LAS content (1000-5000 $\left.\mathrm{g} / \mathrm{cm}^{3}\right)$; and PCE content $\left(100-1000 \mathrm{~g} / \mathrm{cm}^{3}\right)$. The best result $(84.1 \%$ floated) was obtained for combination $\mathrm{pH}=9$, LAS content $=5000$ $\mathrm{g} / \mathrm{cm}^{3}$ and PCE content $=100 \mathrm{~g} / \mathrm{cm}^{3}$

KEYWORDS: Flotation reagents, iron ore flotation, microflotation test, Yates algorithm.

\section{UTILIZAÇÃO DE SULFONATO DE ALQUILBENZENO LINEAR (LAS) E ÉTER DE POLICARBOXILATO (PCE) COMO REAGENTES EM FLOTAÇÃO DE MINÉRIO DE FERRO}

\section{RESUMO}

A flotação é uma das técnicas de separação utilizadas pela indústria mineral e sua importância vem crescendo devido a sua boa performance na concentração de minérios de baixos teores. Reagentes químicos são usados na flotação com a função de promover controle de hidrofobicidade dos minerais dispersos na polpa, entre estes, os surfactantes vêm sendo estudados com bons resultados. Neste estudo, uma substância baseada em sulfonato de alquilbenzeno linear (LAS) e um aditivo para concretos baseado em éter de policarboxilato (PCE) foram testados como reagentes na flotação de minério de ferro. Os testes foram realizados em uma amostra de hematita friável, utilizando a técnica de microflotação. Para o planejamento experimental, foi empregado o método fatorial completo replicado de Yates para três variáveis e dois níveis. As variáveis avaliadas foram o $\mathrm{pH}$ (9 e 11); conteúdo de LAS (1000 e 5000 mg/L); e conteúdo de PCE (100 e 1000 mg/L). O melhor resultado (84,1\% flotado) foi obtido para a combinação $\mathrm{pH}=9$, conteúdo de $L A S=5000 \mathrm{mg} / \mathrm{L}$ e conteúdo de $\mathrm{PCE}=100$ $\mathrm{mg} / \mathrm{L}$.

PALAVRAS-CHAVE: Reagentes para flotação, flotação de minério de ferro, microflotação, algoritmo de Yates. 


\section{INTRODUCTION}

Flotation is a process for selective separation of particulate materials in aqueous medium, (Turrer, 2007). The particles of floating material (hydrophobic nature) are transported to the surface, while the hydrophilic nature material remains deposited in the bottom (Rabockai, 1979). For this purpose, in order to create a stable air-liquid interface with large area, it is necessary shaking or bubbling air through the solution. In this sense admixtures for various purposes are used (Nascimento, 2010). This process is largely employed throughout the world and is applicable to minerals such as sulfides, oxides, phosphates, silicates, etc. (Lima, et al., 2013). The flotation process presents as advantages: favorable performance for low content oxidized ores; possibility of reduction of silica contents in concentrates obtained by magnetic separation; and possibility to produce concentrates for the direct reduction of metallurgical processes (Iwasaki, 1999). In addition, the flotation process has an important environmental factor, allowing the recovery of fine fractions of low-concentration iron ores, commonly rejected for pellet production and sinterfeed (Turrer, 2007). Currently, about $2 \times 109$ ton of ore are processed by flotation (Oliveira, 2007), including an important fraction of all iron ore consumed by the steel industry (Oliveira, 2007). The equipment commonly used in this industry are flotation columns and mechanical cells, which have been modernized to increased efficiency in the last decades (Araujo, et al., 2005; Oliveira, 2007; Valle, 2012; Lima, et al., 2013).

Specific chemical reagents are responsible for the hydrophobicity control of minerals dispersed in a pulp. The flotation of oxides and silicates requires special attention to the electrostatic attraction phenomenon between mineral and collector agent. It thus demands the use of collectors with larger carbon chain and higher collector concentration (Oliveira, 2007). The most used anionic collectors for oxidized minerals are Hexadecyl sulfate, petroleum sulfonates, Octyl hydroxamate, Oleyl sarcosine and $\mathrm{N}$-alkyl sulfosuccinate. Fatty Amines, di-amines, ether amines and ether di-amines are the most common cationic collectors used (Araujo, et al., 2005; Oliveira, 2007).

The hematite is one of the most important Brazilian minerals due to its abundance and elevated iron content. It generally occurs in large compact masses or friable masses with high iron content, but it can also occur in layered structured metamorphic rocks, alternating with quartz (Infomet, 2016).

In flotation process for iron ore, the granulometric range used is 10-150 $\mu \mathrm{m}$ (Araujo, et al., 2005; Lima, et al., 2013). Quartz is the major gangue present in iron ore: and some routes available for its separation are: reverse cationic flotation of quartz; direct anionic flotation of iron oxides; and reverse anionic flotation of activated quartz (Araujo, et al., 2005). The reverse cationic is the most popular flotation route, and amine and cornstarch are the most common collector and depressant used, respectively. (Houot, 1983; Araujo, et al., 2005; Nascimento, 2010; Luo, et al., 2016; Lima, et al., 2016; Ma, et al., 2011). The direct anionic flotation of iron oxides is particularly interesting for the concentration of low grade ores, and fatty acids may be used as collectors (Araujo, et al., 2005). For the anionic reverse flotation route, fatty acids are employed as collector, silicates are activated by $\mathrm{Ca}^{+}$ions, and starch is used as depressant (Lima, 
et al., 2016). Recently, a variety of new more efficient ether-amine collectors have been developed (Ma, et al., 2011).

Various authors have been studying alternative reagents for flotation. Sodium oleate was studied in anionic direct and reverse flotation of iron ore with satisfactory results. In inverse flotation, using cornstarch as depressant has shown similar effects to those observed for amine/starch system. In direct flotation, the best results were obtained using sodium fluorosilicate as quartz depressant (Nascimento, 2010). Carboxymetilcellulose and guar gum were also studied with satisfactory results (Turrer \& Peres, 2010). Poly (N-Isopropyl acrylamide) polymers were studied as flocculants and collectors to form hydrophobic aggregates, and their flotation results for hematite particles above $20 \mu \mathrm{m}$ were than sodium oleate ( $\mathrm{Ng}$, et al., 2015). A new collector type $\alpha$-Bromodecanoid acid was proposed and presented superior performance for quartz flotation in relatively lower temperature. The activation specie was $\mathrm{Ca}(\mathrm{OH})^{+}$in strong alkaline condition (Luo, et al., 2015).

Conversely, surfactants are largely employed in civil construction as chemical admixtures. These products modify the concrete properties, either by incorporating air (air-entraining agents) or improving the consistency (plasticizers and superplasticizers).

The air-entraining agents are used in cement-based composites in order to induce a stable system of microscopic bubbles (Hartman, et al., 2011). The generated pore system increases the durability to freeze-thaw cycles (Du \& Folliard, 2005; Marsh. D, 2015). In addition, air entraining is desirable in order to produce lighter and more thermal insulating concretes and mortars (Schackow, et al., 2014). The main employed air-entraining substances are vinsol resin, tall oils, fatty acids, alkylaryl sulfonates and sulfates, alkylaryl ethoxilates, acid salts and alkaline amines of lignosulfonate (Hartman, et al., 2011; Yang, et al., 2000). Recently, the use of Linear Alkylbenzene Sulfonate (LAS), a biodegradable surfactant from dishwashing liquids, as airentraining agent for cement-based materials has presented successful results (Mendes, 2016).

The LAS is an anionic surfactant that presents one long non-polar portion (hydrophobic) and one small polar group (hydrophilic). The LAS belongs to a family of synthetic detergents and is the active principle of dishwashing liquids. As advantages, these products are widely available, low cost, are non-toxic and present low environmental impact with a biodegradation ratio up to 95\% (Ypê, 2011, Mendes, 2016). Fig. 1a shows a schematic arrangement of LAS molecule.

In turn, plasticizers and superplasticizers are used in cement-based materials in order to increase de workability of fresh mixtures without increase the water consumption. The commercially available plasticizers are based on lignosulfonates, hydroxycarboxylic salts, and polysaccharides; the first being the most common. The first-generation superplasticizers are based on condensed salts of naphthalene sulfonates or melanin sulphonate and the secondgeneration are based on polycarboxylate-ethers (PCEs)(Hartman, et al., 2011; Liu, et al., 2014). The plasticizers and superplasticizers polymers have a great number of hydrophilic branching in their hydrophobic chain. This way, a part of the hydrophilic branches is adsorbed by the cement particle, while the other part is oriented for water, making the particle hydrophilic (Mehta \& Monteiro, 2014).

PCEs can be classified as two categories: polyester-type and polyether-type PCE (Liu, et al., 2014). The architecture of the PCE polymers consists in a main chain and various side chains. 
The main chain is adsorbed by the particle while side chains provide a dispersant effect. Fig. $1 b$ shows the schematic arrangement of a polycarboxylate molecule.

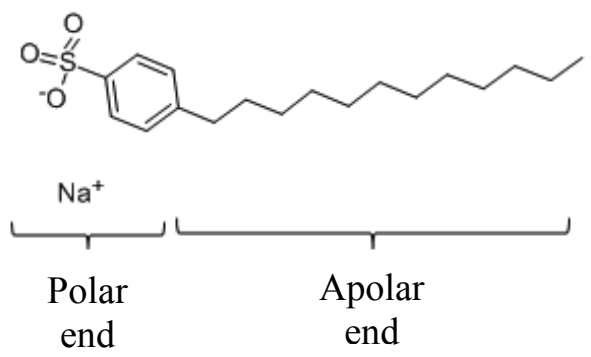

a)

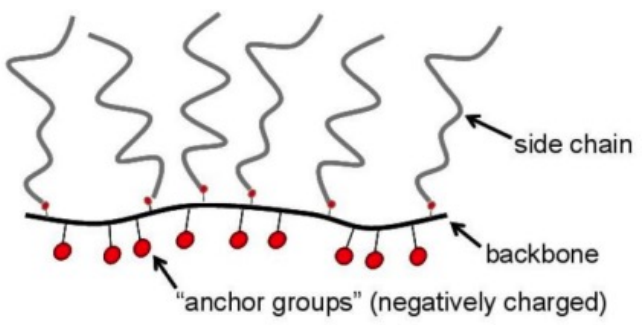

b)

Fig. 1. a) Molécula de LAS com suas extremidades polar e apolar (CHEMICAL BOOK, 2016); b) Arranjo esquemático de uma molécula de policarboxilato (SIKA, 2016).

Therefore, the present research aims to investigate the utilization of a LAS-based dishwashing liquid and a PCE-based commercial superplasticizer as polymeric reagents for iron ore flotation.

\section{MATERIALS AND METHODOLOGY}

In this study, samples of friable hematite were used in order to perform microflotation tests. The material was processed in a Dalmatica SM100 mill, with $5 \mathrm{~s}$ milling time, and the fraction 150-300 $\mathrm{mm}$ was used. The samples were prepared and divided according to prescriptions of standard NBR ISO 3082 (ABNT, 2011).

The LAS-based material employed was a commercial dishwasher detergent brand Ypê and the PCE-based substance was a chemical concrete superplasticizer brand Mc-Balchemie Powerflow4000. $\mathrm{NaOH}$ and $\mathrm{HCL}$ were used for $\mathrm{pH}$ adjustment.

The microflotation tests were performed in the Laboratory of Flotation, Department of Mining Engineering, Universidade Federal de Ouro Preto. A Hallimond modified tube, a magnetic mixer and a nitrogen font with rotameter were employed. In Fig. 2 is shown the assembly of the apparatus used.

The testes were performed in $2 \mathrm{~g}$ iron ore samples, conditioned for 6 minutes in a $50 \mathrm{~mL}$ solution containing the reagents. The gas flux was set in $90-120 \mathrm{~mL} / \mathrm{min}$; the flotation time was set in 1 minute; and de mix speed in $4 \mathrm{rpm}$. The tests were carried out in accordance with the statistical plan specified in Table 1. It uses the complete replicated factorial method for three variables and two levels (Box, et al., 1978). The variables adopted were $\mathrm{pH}(\mathrm{A})$, LAS content (B), and PCE content (C). Two experimental levels were adopted for each variable, superior $(+)$ and inferior (-). 


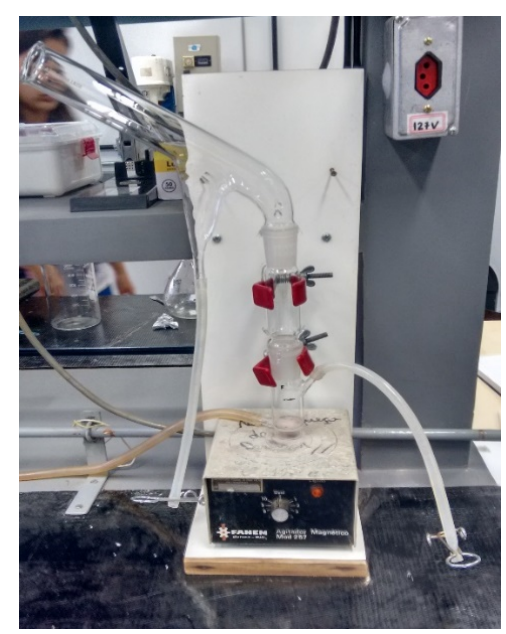

Fig. 2. Aparatus used in microflotation tests

The PCE content was fixed in accordance with the minimum dosage recommended by the manufacturer (MC Bauchemie, 2015). This dosage was converted in PCE/water ratio to better adjust test conditions. The LAS content was fixed using the same PCE/water ratio, considering $10 \%$ LAS concentration in the commercial dishwashing liquid (Ypê, 2014). For the LAS superior level, the authors used half of the PCE concentration, in order to avoid the excess foam formation. The $\mathrm{pH}$ maximum value was fixed seeking to simulate the concrete environment, theoretically the best condition for PCE-based reagent action.

Table 1. Adopted data in experimental plan.

\begin{tabular}{|c|c|c|c|}
\hline \multirow{2}{*}{ Variable } & \multirow{2}{*}{ Id. } & \multicolumn{2}{|c|}{ Experimental levels } \\
\hline & & Inferior (-) & Superior (+) \\
\hline $\mathrm{pH}$ & $A$ & 9 & 11 \\
\hline LAS content, mg/L & B & 1000 & 5000 \\
\hline PCE content, mg/L & C & 100 & 1000 \\
\hline
\end{tabular}

\section{RESULTS AND DISCUSSION}

The best results were observed for tests $B(p H=9$; LAS content $=5000 \mathrm{mg} / \mathrm{L} ;$ PCE content $=100 \mathrm{mg} / \mathrm{L}) ; \mathrm{AC}(\mathrm{pH}=11 ; \mathrm{LAS}$ content $=1000 \mathrm{mg} / \mathrm{L} ; \mathrm{PCE}$ content $=1000 \mathrm{mg} / \mathrm{L})$ and $\mathrm{T}(\mathrm{pH}=9$; LAS content $=1000 \mathrm{mg} / \mathrm{L}, P C E$ content $=100 \mathrm{mg} / \mathrm{L})$. The results suggest a better collector performance for LAS with higher and moderate concentration in lower $\mathrm{pH}$ value, while PCE presented best collector performance with higher concentration for higher $\mathrm{pH}$ value (as expected, considering the high $\mathrm{pH}$ environment of cement-based composites).

Depressant behavior was observed in $A B$ test $(p H=11$; LAS content $=5000 ;$ PCE content $=$ 100), which suggests a depressant effect of high LAS content associated with high $\mathrm{pH}$ value. In $\mathrm{C}$ test $(\mathrm{pH}=9$; LAS content $=1000 \mathrm{mg} / \mathrm{L} ;$ PCE content $=1000 \mathrm{mg} / \mathrm{L})$ was observed a moderate depressant effect, indicating a depressant action in the association of high PCE content with low $\mathrm{pH}$ value. 
In general, the tests involving similar levels of LAS and PCE presented intermediate behavior, what suggests that these two surfactants have antagonist effect when associated.

The tests results are shown in Fig. 3. The matrix of the factorial method is presented in Table 2.

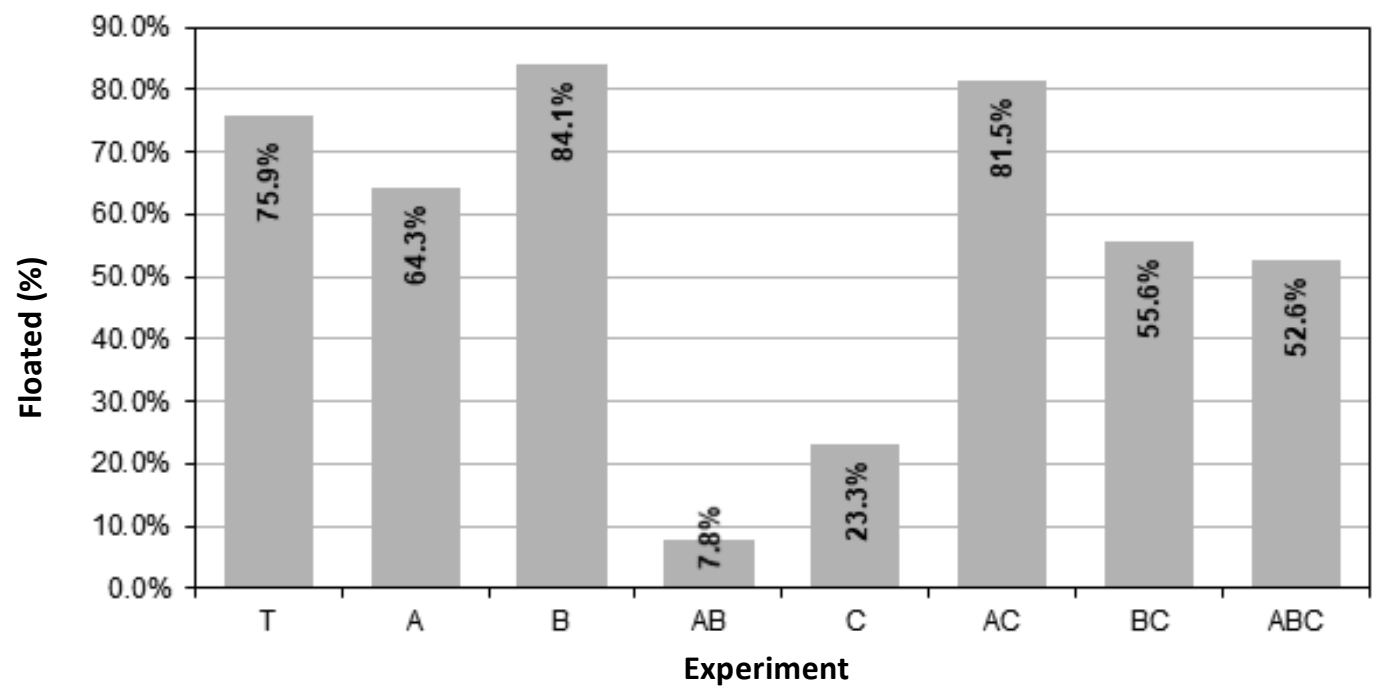

Fig. 3. Experimental results.

Table 2. Experimental results from the block matrix of the complete factorial method.

\begin{tabular}{|c|c|c|c|c|c|c|c|}
\hline \multirow{2}{*}{ Test } & \multirow{2}{*}{ A } & \multirow{2}{*}{ B } & \multirow{2}{*}{ C } & \multirow{2}{*}{ Id. } & \multicolumn{3}{|c|}{ Floated (\%) } \\
\hline & & & & & $\mathbf{R}_{1}$ & $\mathbf{R}_{\mathbf{2}}$ & Average value \\
\hline 1 & - & - & - & $\mathrm{T}$ & 76.2 & 75.6 & 75,9 \\
\hline 2 & + & - & - & A & 63.3 & 65.3 & 64,3 \\
\hline 3 & - & + & - & B & 88.8 & 79.3 & 84,1 \\
\hline 4 & + & + & - & $A B$ & 5.4 & 10.2 & 7,8 \\
\hline 5 & - & - & + & C & 22.6 & 24.0 & 23,3 \\
\hline 6 & + & - & + & $A C$ & 77.2 & 85.7 & 81,5 \\
\hline 7 & - & + & + & $B C$ & 58.9 & 52.3 & 55,6 \\
\hline 8 & + & + & + & $A B C$ & 54 & 51.2 & 52,6 \\
\hline
\end{tabular}

The Yates calculations showed that, except for $A B C$ test, all variables and interactions are significant at $95 \%$ confidence level. Additionally, for all considered variable separately, the change in the value from the inferior level to superior level leads to a decrease in the response variable value. The results are shown in Table 3.

The influence of the interactions of two variables $(A B, B C$, and $A C)$, showed to be significant in the factorial method. Therefore, these interactions were made explicit using the inverse Yates algorithm. As result, it was observed that for interaction $A B$, the variable $A$ should be considered at its higher value and variable $B$ at its lower value, for a higher response. For interaction $B C$, the method showed that variables $B$ and $C$ should be considered in their lower value. Finally, for interaction $A C$, the variables $A$ and $C$ should be considered at their lower values for better results. 
Table 3. Yates algorithm for three variables and two levels.

\begin{tabular}{|c|c|c|c|c|c|c|c|c|c|c|}
\hline \multirow{2}{*}{ R1+R2 } & \multicolumn{9}{|c|}{ Yates algorithm } & \multirow{2}{*}{ Effect } \\
\hline & Y-1 & $Y-2$ & $Y-3$ & $A D$ & Effect & (R1-R2) & $(R 1-R 2)^{n} 2$ & $\tau$, cal & Significance & \\
\hline 151.87 & 280.48 & 464.14 & 889.98 & 111.25 & $\mathrm{~T}$ & 0.57 & 0.33 & - & - & - \\
\hline 128.61 & 183.67 & 425.84 & -65.51 & -8.19 & A & -1.97 & 3.90 & 4.21 & $S$ & Decrease \\
\hline 168.12 & 209.49 & -175.82 & -89.95 & -11.24 & B & 9.43 & 88.93 & 5.79 & $S$ & Decrease \\
\hline 15.55 & 216.35 & 110.32 & -251.63 & -31.45 & $A B$ & -4.75 & 22.60 & 16.18 & $S$ & Decrease \\
\hline 46.58 & -23.26 & -96.81 & -38.31 & -4.79 & C & -1.45 & 2.11 & 2.46 & $S$ & Decrease \\
\hline 162.90 & -15256 & 6.86 & 286.14 & 35.77 & $A C$ & -8.55 & 73.18 & 18.40 & $S$ & Increase \\
\hline 111.18 & 116.32 & -129.31 & 103.67 & 12.96 & $B C$ & 6.55 & 42.89 & 6.67 & $S$ & Increase \\
\hline 105.17 & -6.00 & -122.32 & 6.99 & 0.87 & $A B C$ & 2.79 & 7.81 & 0.45 & $\mathrm{~N}$ & Increase \\
\hline
\end{tabular}

The interaction of the factors was analyzed using inverse Yates algorithm. The calculations for the interaction analyses are shown in Table 4.

Tabela 4. Inversed Yates algorithm for interactions

\begin{tabular}{ccccc}
\hline Effect & DM & Y-1 & Y-2 & $(\mathbf{Y - 2}) / \mathbf{2}$ \\
\hline AB & $-31,45$ & $-42,70$ & 60,36 & 30,18 \\
B & $-11,24$ & 103,06 & 139,65 & 69,82 \\
A & $-8,19$ & 20,21 & 145,76 & $\mathbf{7 2 , 8 8}$ \\
T & 111,25 & 119,44 & 99,23 & 49,61 \\
\hline BC & 12,96 & 8,17 & 108,18 & 54,09 \\
C & $-4,79$ & 100,00 & 104,74 & 52,37 \\
B & $-11,24$ & $-17,75$ & 91,83 & 45,92 \\
T & 111,25 & 122,49 & 140,24 & $\mathbf{7 0 , 1 2}$ \\
\hline AC & 35,77 & 30,98 & 134,04 & 67,02 \\
C & $-4,79$ & 103,06 & 78,88 & 39,44 \\
A & $-8,19$ & $-40,56$ & 72,08 & 36,04 \\
T & 111,25 & 119,44 & 159,99 & $\mathbf{8 0 , 0 0}$ \\
\hline
\end{tabular}

\section{CONCLUSION}

The results showed better collector effect in tests $B\left(p H=9\right.$; LAS content $=5000 \mathrm{~g} / \mathrm{cm}^{3} ;$ PCE content $\left.=100 \mathrm{~g} / \mathrm{cm}^{3}\right), A C(\mathrm{pH}=11 ;$ LAS content $=1000 \mathrm{mg} / \mathrm{L} ;$ PCE content $=1000 \mathrm{mg} / \mathrm{L})$ and $\mathrm{T}(\mathrm{pH}$ = 9; LAS content $=1000 \mathrm{mg} / \mathrm{L}, \mathrm{PCE}$ content $=100 \mathrm{mg} / \mathrm{L}$ ), which presented floated content equal to $84.1 \%$; $81.4 \%$; and $75.9 \%$ respectively.

The tests AB $(\mathrm{pH}=11$; LAS content $=5000 ;$ PCE content $=100)$, and $C(\mathrm{pH}=9$; LAS content $=1000 \mathrm{mg} / \mathrm{L} ; \mathrm{PCE}$ content $=1000 \mathrm{mg} / \mathrm{L}$ ), presented depressant behavior, with observed floated content of $7.8 \%$ and $23.3 \%$ respectively.

The Yates calculations showed that all variables ( $\mathrm{pH}$; LAS content; and PCE-content) were significant for a $95 \%$ confidence level, as well as interactions pH/LAS-content; $\mathrm{pH} / \mathrm{PCE}$-content; HOLOS, Ano 33, Vol. 06 
and LAS-content/PCE-content. Additionally, the decrease in the individual variable values should be applied for an increasing in floated content.

The interactions were evaluated using inverse Yates algorithm and the tests showed an increase in response in these three combinations: a high $\mathrm{pH}$ value associated with a low LAS content; a low pH value associated with a low PCE content; and a low LAS content associated with a low PCE content.

Therefore, tested LAS-based and PCE-based compounds presented promising results as reagents for iron ore flotation. They are widely available, non-toxic and have relative low cost; with LAS also being a biodegradable surfactant. Therefore, these materials present a potential alternative to the current flotation process of low-content iron ore.

\section{AGRADECIMENTOS}

The authors gratefully acknowledge CAPES, FAPEMIG, CNPq, UFOP, UFV and Fundação Gorceix for providing financial support. We are also grateful for the infrastructure and collaboration of the Laboratory of Flotation (UFOP) and its researchers.

\section{REFERENCES}

ABNT. (2011). Aditivos químicos para concreto de cimento Portland - Especificações. NBR 11768. Rio de Janeiro: Associação Brasileira de Normas Técnicas - ABNT.

ABNT. (2011). Minérios de ferro - Procedimentos de amostragem e preparação de amostras. NBR ISO 3082. Rio de Janeiro: Associação Brasileira de Normas Técnicas - ABNT.

Araujo, A. C., Viana, P. M., \& Peres, A. C. (2005). Reagents in iron ore flotation. Minerals Engineering, 18(2005), 219-224.

Box, G. P., Hunter, W. G., \& Hunter, J. S. (1978). Statistics for experiments: an introduction for design, data analysis, and model building. John Wiley \& Sons Inc.

Chemical book. (2016). Sodium dodecylbenzenesulphonate. Retrieved December 19, 2016, from http://www.chemicalbook.com/ChemicalProductProperty_EN_CB4852054.htm

Du, L., \& Folliard, K. J. (2005). Mechanisms of air entrainment in concrete. Cement and Concrete Research, 35, 1463-1471.

Hartman, C., Jeknavorian, A., Silva, D., \& Benini, H. (2011). Aditivos químicos para concretos e cimentos. In G. C. Isaia (Ed.), Concreto: ciência e tecnologia (pp. 347-380). São Paulo: Ibracon.

Houot, R. (1983). Beneficiation of iron ore by flotation - Review of industrial and potential applications. International Journal of Mineral Processing, 10(1983), 183-204.

Infomet. (2016). Minérios de ferro. Retrieved September 29, 2016, from Infomet: http://www.infomet.com.br/site/siderurgia-1a-minerios.php

Iwasaki, I. (1999). Iron Ore Flotation - Historical Perspective and Future Prospects. In SME, B. K. Parekh, \& J. D. Miller (Eds.), Advances in Flotation Technology. Denver: Society for Mining, 
Metallurgy, and Exploration, Inc. - SME.

Lima, N. P., Pinto, T. S., Tavares, A. C., \& Sweet, J. (2016). The entrainment effect on the performance of iron ore reversse flotation. Minerals Engineering, 96-97, 53-58.

Lima, N. P., Valadão, J. S., \& Peres, A. C. (2013). Effect of particle size range on iron ore flotation. Revista Escola de Minas, 66(2), 251-256.

Liu, X., Wang, Z., Zhu, J., Zheng, Y., Cui, S., Lan, M., \& Li, H. (2014). Synthesis, characterization and performance of a polycarboxylate superplasticizer with amide structure. Colloids and Surfaces A, 448, 119-129.

Luo, B., Zhu, Y., Sun, C., Li, Y., \& Han, Y. (2015). Flotation and adsorption of a new collector alphaBromodecanoic acid on quartz surface. Minerals Engineering, 77, 86-92.

Luo, X., Wang, Y., Wen, S., Ma, M., Sun, C., Yin, W., \& Ma, Y. (2016). Effect of carbonate minerals on quartz flotation behavior under conditions of reverse anionic flotation of iron ores. International Journal of Mineral Processing, 152, 1-6.

Ma, X., Marques, M., \& Gontijo, C. (2011). Comparative studies of reverse cationic/anionic flotation of Vale iron ore. International Journal of Mineral Processing, 100, 179-183.

Marsh. D. (2015). Besting Bubbles. Concrete Products, 118, 66-68.

MC Bauchemie. (2015, November). MC-Powerflow4000 - Datasheet. Retrieved February 02, 2017, from MC-Bauchemie: http://www.mc-bauchemie.com.br/wpcontent/uploads/2013/12/mc-powerflow-4000-11-2015.pdf

Mehta, P., \& Monteiro, P. M. (2014). Concrete: microstructure, properties and materials (2nd. ed.). São Paulo: Ibracon.

Mendes, J. C. (2016). Technical feasibility of Linear Alkylbenzene Sodium Sulfonate use as airentraining agent for cement-based materials. Master's thesis, Escola de Minas, Universidade Federal de Ouro Preto. Ouro Preto: UFOP.

Nascimento, D. R. (2010). Anionic flotation of iron ore. Master's thesis - Escola de Minas, Universidade Federal de Ouro Preto, 116. Ouro Preto: UFOP.

Ng, W. S., Sonsie, R., Forbes, E., \& Franks, G. V. (2015). Floculation/flotation of hematite fines with anionic temperature-responsive polymer acting as selective flocculants and collector. Minerals Engineering, 77, 64-71.

Oliveira, J. F. (2007). Flotation. In M. T. CETEM, Brazil technological trends 2015: Geosciences and mineral technologies. Rio de Janeiro: CETEM/MCT.

Rabockai, T. (1979). Physical Chemistry of Surfaces. OEA.

Schackow, A., Effting, C., Folgueras, M. V., Guths, S., \& Mendes, G. A. (2014). Mechanical and thermal properties of ligthweight concretes with vermiculite and EPS using air-entraining agents. Construction and Building Materials, 57, 190-197.

Sika. (2016). Superplasticizers. Retrieved December 19, 2016, from http://deu.sika.com/en/gypsum-mortar-redirect/sika-gypsum-mortars-solutions/gypsumproduct-groups/superplasticizers.html

Turrer, H. D. (2007). Polymer depressants in iron ore flotation. Doctoral dissertation - Engenharia 
Metalúrgica e de Minas, Universidade Federal de Minas Gerais, 203. Belo Horizonte: UFMG.

Turrer, H. D., \& Peres, A. E. (2010). Investigation on alternative depressants for iron ore flotation. Minerals Engineering, 23, 1066-1069.

Valle, T. A. (2012). Use of aerators in floatation: historical, concepts and emerging trends. Bachelor's thesis - Engenharia de Minas, Universidade Federal de Minas Gerais, 36. Belo Horizonte: UFMG.

Yang, Q., Zhu, P., Wu, X., \& Huang, S. (2000). Properties of concrete with a new type of saponin air-entraining agent. Cement and Concrete Research, 30(8), 1313-1317.

Ypê. (2011, October 19). Impakto. Retrieved February 02, 2017, from https://www.impakto.com.br/sistema/produtoEspecificacao/110029.pdf

Ypê. (2014, April 3). Pratika. Retrieved February 2, 2017, from http://www.pratika.com.br/files/site/uploads/produtos/DETERGENTE_YPyU_500ml__QUIMICA_AMPARO.pdf 